\title{
A KÉSZLETGAZDÁLKODÁS OPTIMALIZÁLÁSÁNAK MÓDSZEREI, A KÉSZLETTARTÁSI RÁTA DIAGNÓZISA
}

\author{
Pupos Tibor ${ }^{1}$-Kovács Zoltán ${ }^{2}$ - Kis-Simon Tünde ${ }^{3}$ - Pintér Gábor ${ }^{4}$ \\ 'egyetemi tanár, ${ }^{2}$ vezérigazgató, ${ }^{3} \mathrm{Ph} . \mathrm{D}$. hallgató, tanársegéd ${ }^{4}$, \\ Pannon Egyetem, Georgikon Kar, Keszthely \\ 'IMMOGLOBÁL Zrt. Szeged
}

\begin{abstract}
SUMMARY
The standard of stockpiling has an important role in the life of companies every time. This role basically correlates with the economic effects of the stockpiling. The results and definitions in the related sources have many paradoxes. They are deficient or bad explained many times. The theme of this study is the known methods and algorithms which theoretic base is not questionable but which practical usage has many problems. In the framework of the study we reveal the importance of concretizing variables in the contexts, we interpret their economic content, we define the problems coming forward in case of their practical application, and we make a proposal for concretizing the variables and for the algorithm of their practical application.
\end{abstract}

\section{ÖSSZEFOGLALÓ}

A készletgazdálkodás színvonala mondhatni folyamatosan napirenden van a vállalatok életében. E megkülönböztetett szerep alapvetően a készletgazdálkodás gazdasági hatásaival van összefüggésben. A kapcsolódó forrásmunkákban közölt eredmények, a fogalmak értelmezése sok esetben hiányos, vagy rosszul értelmezett. Jelen tanulmányban a készletgazdálkodással összefüggésben azon ismert módszerek és algoritmusok képezik a kutatás tárgyát, melyeknek elméleti megalapozottsága nem vitatható, de gyakorlati alkalmazásuk több problémát is felvet. A tanulmány keretében feltárjuk a kapcsolódó összefüggésekben szereplö változók számszerüsítésének fontosságát, értelmezzük gazdasági tartalmukat, meghatározzuk a gyakorlati alkalmazásuk során jelentkezö problémákat, és javaslatot teszünk a változók számszerüsítésének és gyakorlati alkalmazásuk algoritmusára.

\section{A KAPCSOLÓDÓ FOGALMAK ÉRTELMEZÉSE}

Mint a hazai, mint a külföldi szakirodalomban a kapcsolódó fogalmak értelmezése nem nevezhető egységesnek, a szerzök a forgótőkét a forgóeszközök teljes állományával, vagy a nettó forgótőkével veszik azonosnak. A Közgazdasági ABC (1973: 158.o.) szerint: „A forgótőke a termelötőkének azok az elemei, amelyek egy termelési periódusban elhasználódnak és értéküket átadják az új terméknek" Ez a megfogalmazás a forgótökét a termelésben felhasznált forgóeszközökkel veszi azonosnak. Tartalmilag teljesen azonos definíciókat találhatunk az alábbi forrásmunkákban: Közgazdasági kislexikon (1987:173. o. ; Magyar Nagylexikon (2003: 628. o.). Hámori (2000: 46. o.) szerint: "Current assets" forgótőke egy vállalat vagyonának másik része az állótőke mellett. $A$ forgótőkének három fő összetevője van: $A z$ elsö az alaptőke, beleértve a készárut, fékész árut és a nyersanyagokat;....A második tétel a számlakövetelések és rövid lejáratú adósok.....A harmadik elem a készpénz és a rövidlejáratú befektetések. A forgótöke mérete különösen a pénzügyi arányok szempontjából a vállalat likviditásának fö mutatója." A szerző végső soron a forgóeszközök teljes állományát tekinti forgótökének. Hogy a forgótőkét, miért lehet a likviditás fó mutatójának tekinteni, az, az olvasó számára csak a forrásmunka alapján nem ítélhetö meg.

Tartalmilag lényeges különbség fedezhetö fel azon szerzők munkájában, akik a forgótőkét a nettó forgótőkével veszik azonosnak. A témakörrel összefüggésben mondhatni alapirodalomnak számít Brealey/Myers (1993: 464-473. o.) munkája, melyben a szerzők a 
forgótökét a lekötött forgóeszközök és a folyó források összességeként értelmezik, mint a forgótöke összetevöit, azaz elemeit. A forgótöke müködései ciklusát a

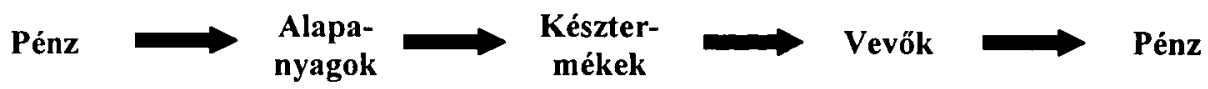

folyamatos alakváltozások sorozatként tüntetik fel. A fenti összefüggés alapján igaz lenne, hogy a forgótőke egyenlő azzal a pénzmennyiséggel, amely egy körforgás megvalósításához szükséges? A müködési ciklus sajátosságaihoz kapcsolódóan a szerzők az alábbiak szerint fogalmaznak: „Egyetlen állandó elem szerepel ebben a folyamatban - nevezetesen a forgótőke. A forgótőke összetevöi folyamatosan változnak. Ez az egyik oka annak, amiért a (nettó) forgótőkét jó összefoglaló mutatónak tartják a forgóeszközökre és a folyó forrásokra." Egyértelmű lenne a forgótőke definíciója, ha nem szerepelne ott a zárójelben lévő „,nettó” jelzö, valamint a folyó forrásokra való hivatkozás, ha csak a forgótőke müködési ciklusáról van szó. Véleményünk szerint a müködési ciklus tökeigénye és a ciklus forrásigénye, illetve annak struktúrája külön-külön vizsgálandó. Hangsúlyozottan kell megemlíteni azt is, hogy a tökeigény és forrásigény nem ugyanazt takarja, mivel szerepük a finanszirozásában teljesen eltérö. A szerzök a továbbiakban az alábbiak szerint fogalmaznak: „A forgótöke - mint méröszám - erössége abban rejlik, hogy nincsenek rá hatással a különbözö forgóeszközök és folyó források átmeneti, vagy szezonális jellegü változásai." Ha ez így van, akkor a forgótőke - adott termelési folyamatra jellemző feltételek keretei között - állandó összegü tőkelekötésre enged következtetni. Hivatkozott szerzök véleményével összhangban Illés I-né (1994), hivatkozva az angolszász országok gyakorlatára is, úgy ítéli meg, hogy a forgóeszközöket (current assets) forgótökének nevezik (working capital), majd az alábbiak szerint fogalmaz: „Kitüntetett szerepe azonban a nettó forgótőkének van (net working capital), amely a forgóeszközök és a rövid lejáratú kötelezettségek (current laibilities) különbsége. A nettó forgótöke tehát a forgóeszközöknek az a többlete, amit tartós forrásokkal (saját tökével és hosszú lejáratú kötelezettségekkel) kell finanszirozni." Nem lehet egyetérteni ezzel a megfogalmazással. Véleményünk szerint nem a forgóeszközök többletéröl, hanem annak csak adott hányadáról van, illetve lehet szó. A szerzö - elözőekben hivatkozott munkájában részletesen ír az idöbeliség elve érvényesítésének fontosságáról a finanszírozási stratégiák megválasztása kapcsán. Megállapítja, hogy egy fejlődő vállalkozás zavartalan müködéséhez befektetett eszközökre és tartósan lekötött forgóeszközökre, valamint átmenetileg szükséges forgóeszközökre van szükség. Ez utóbbiak „a gazdaság ciklikussága, valamint a termelés vagy értékesítés szezonalítása miatt, bizonyos szabályszerüséggel a trend körül változik. Másik része elöre megjósolhatatlan, napról-napra, hónapról-hónapra fluktuál." A fentiek alapján igaz lenne, hogy a forgótöke azonos a tartósan lekötött forgóeszközökkel? A forgótökének olyan értelmezése is elöfordul, amikor a forgótökét a nettó forgótökével veszik azonosnak, és a forgótökét a mérleg adatai alapján számszerüsítik, és ennek alapján értelmezik.

$$
\begin{aligned}
& \text { NFT }=(\text { FE }+ \text { AIE-CT })-(\text { RLK }+ \text { PIE }) \\
& \text { ahol }
\end{aligned}
$$

NFT $=$ Nettó forgótőke, $\mathbf{F E}=$ Forgóeszközök, AIE $=$ Aktiv időbeli elhatárolások

$\mathbf{C T}=$ Céltartalék, $\mathbf{R L K}=$ Rövid lejáratú kötelezettségek, PIE $=$ Passzív idöbeli elhatárolások 
A fenti összefüggés alapján, a nettó forgótőke értelmezése - amelyet a számítás módja a kötelező mérleg-egyezőség miatt egyébként egyértelmủen determinál - nem is lehet más. Arra azonban fel kell hívni a figyelmet, hogy a fenti értelmezés alapján a nettó forgótőkének van/lehet egy fontos sajátossága, nevezetesen, - amit egyébként gyakorlati tényszámok is bizonyítanak -, hogy értéke lehet negatív is. Ez az eset viszont éppen arra hívja fel a figyelmet, hogy a nettó forgótőke nem lehet azonos a forgótőkével, mert a nettó forgótőke csak az időbeliség elvére enged következtetni. Ugyanis, ha a nettó forgótőke negatív, az a vállalat agresszív finanszírozási stratégiájára utal, amely olyan fokú, hogy a befektetett eszközök adott állományát is rövid lejáratú források finanszírozzák. Ilyen esetben viszont a fenti definíciókat nem lehet értelmezni

A területtel foglalkozó forrásmunkák alapján megállapitható, hogy mind a nemzetközi, mind pedig a hazai szakirodalomban a kapcsolódó fogalmak értelmezése nem egységes, az általánosság szintjén mozog, ellentmondásos, mivel szakmai és elméleti megalapozottságuk hiányzik. Az egyes értelmezések nem tesznek különbséget a töke és a folyó termelés költségei fogalmak között. Nem vizsgálják a forgóeszközök egyes elemeinek a termelési folyamatban betöltött szerepét. Nem tárják fel az idöbeliség ok-okozati összefüggéseit, ezért az eszközstruktúra és forrásstruktúra kapcsolatrendszere vizsgálatát is csak a mérleg szintjén végzik el. Mindezek alapján a kapcsolódó fogalmak, mint a forgótőke, idényszerüen jelentkezö forgóeszközök, forgóbefektetés, nettó forgótöke sem lehet egységes és szakmailag megalapozott.

Az elméleti összefüggések megértése, az ok-okozati összefüggések feltárása céljából vegyük alapul a termelési folyamatot, mint gazdasági rendszert, de fókuszáljunk annak gazdasági hatásaira, azaz kezeljük azt úgy, mint értékteremtő folyamat. Ha ezt megtesszük és elfogadjuk az említett szempontokat, akkor az 1. ábra összefüggéseit kapjuk. Ez képezi elméleti alapját a forgótőke és a kapcsolódó fogalmak értelmezésének. Fogadjuk el, hogy a vállalat csak egyféle terméket gyárt, anyacsavart. Ismert, hogy a termelés során a termelési folyamatba inputok áramlanak be, és a termelési folyamat sajátosságainak megfelelően, megtörténik azok transzformációja outputokká. Gazdasági szempontból ezek az inputok a forgóeszközök.

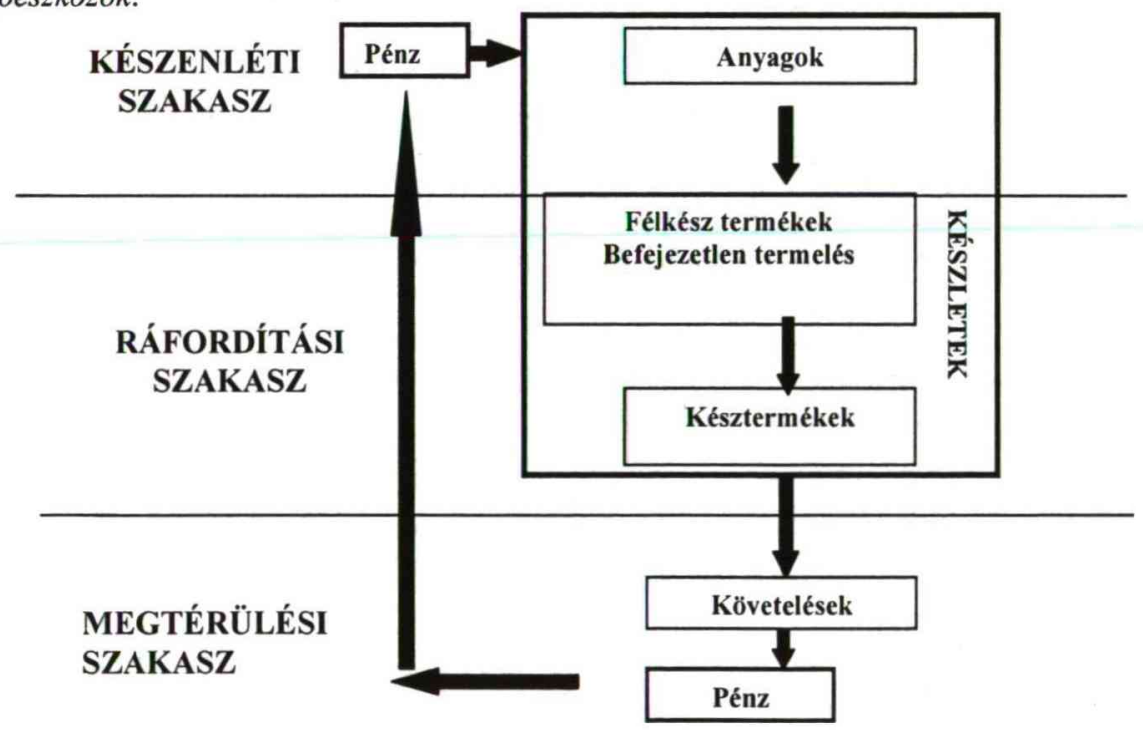

1. ábra. A forgóeszközök körforgása, mint a forgótőke értelmezésének elméleti alapja Forrás: Szerzők saját munkája 
A 1 . ábra alapján megállapítható - ami a valóságban is így van -, hogy a forgóeszközök elsö megjelenési formája a pénz. A pénz teszi lehetővé, hogy inputokat vásároljunk. A pénzt tehát átváltjuk a végtermék elöállításához szükséges forgóeszközökre, gömbvasra. A termelési folyamat még nem indult meg, de felkészültünk annak inditására. Ezt a szakaszt készenléti szakasznak nevezzük. A termelés a gömbvas darabolásával kezdödik. Ennek a végterméke a darabolt gömbvas, mint félkész termék. A termelési folyamat eredménye lesz az anyacsavar, mint késztermék. A termelés indításától a késztermék megjelenéséig tart a termelési szakasz. Ezt követi az értékesítés. Az ellenérték, azaz az árbevétel átutalásáig követelésállomány is keletkezik. Ez a szakasz a megtérülési szakasz, melynek eredménye ismét a pénz lesz.

A vázolt összefüggések alapján látható, hogy az értékteremtö folyamat végsö soron a forgóeszközök körforgását jelenti. A forgóeszközök körforgásán a forgóeszközök folyamatos alakváltozásának sorozatát értjük, amikor a pénzformából - a termelési folyamat sajátosságaitól és a kapcsolódó befektetetési, szervezési döntésektöl is függöen - üjra pénzformához jutunk. A termelési folyamat sajátosságai, a menedzsment kapcsolódó döntései miatt a körforgás egyes elemei más-más formában jelennek meg, illetve öltenek testet, pl. a befejezetlen termelés nem minden termelési folyamat (szolgáltatás elöállítása) működési ciklusában jelenik meg, készpénzes értékesítés esetén a követelés állománnyal sem kell számolni. Az ábráról az is leolvasható, hogy a forgóeszközök vázolt megjelenési formái között vannak olyan elemek is, amelyek a forgóeszközök müködési ciklusában nem jelennek meg, pl. értékpapírok, készletre adott elölegek, alapítókkal szembeni követelések, egyéb követelések, stb. Ezek az elemek tehát nem elemei a körforgásnak, de szerepeltetésük a vagyonmérlegben természetesen indokolt.

$\mathrm{Az}$ ok-okozati összefüggések feltárása érdekében tovább kell lépni, mivel nem elegendő csak a körforgás és elemeinek értelmezése. A körforgásban megjelenö forgóeszközféleségeket abból a szempontból is vizsgálni szükséges, hogy azok milyen szerepet töltenek be a termelés folyamatosságának biztositásában. Ez a terület az, amelyet hivatkozott szerzők teljesen figyelmen kívül hagynak, sem a nemzetközi, sem pedig a hazai szakirodalom nem vizsgálja a fennálló összefüggéseket. A körforgás folyamatossága ugyanakkor csak ezen összefüggések által biztosított. A továbbiakban értelmezzük a körforgás forgóeszközeinek termelési folyamatban betöltött szerepét úgy, hogy nyomon követjük a körforgást.

Az elözöekben említett példát vegyük alapul. Feltételezzük, hogy a termelés egyenletes, az értékesités 10 naponként történik, a fizetési határidö 20 nap, az alapanyag beszerzés a termelés intenzitásának megfelelöen történik, és a biztonsági alapanyagkészlet öt nap termelési igényének felel meg. A késztermék készlet - a nem pontosan prognosztizálható kereslet miatt - legyen azonos szintén ôt nap termelésével.

Belátható, hogy a folyamatos termelés elengedhetetlen feltétele, hogy az egyes szakaszok találkozásánál (szakadási pontok) készletek képzödjenek, továbbá az, hogy a vállalat kereskedelmi hitelezési politikájától függően - a fizetési határidő hossza - a követelésállomány is állandó eleme lesz a müködési ciklusnak. Levonhatjuk azt a következtetést, hogy a folyamatos termelés vitelének elengedhetetlen feltétele, hogy a körforgásban megjelenő forgóeszközök - pénz, készletek, követelések - a termelési folyamat sajátosságai, a kapcsolódó gazdasági döntések által meghatározottan, egymás mellett egyidejüleg kell, hogy létezzenek, azaz állandó jelleggel lekötve legyenek. Hogy a bennük állandó jelleggel lekötött pénz értékösszege mekkora, az, nagymértékben függ a termelési folyamat sajátosságaitól, a kapcsolódó döntésektől, pl. fizetési határidök, készletgazdálkodás színvonala, fizetési módok, biztonsági pénzkészlet állománya stb. is.

A folyamatos termelés vitele azzal is együtt jár, hogy a termelésnek költségei vannak. Ezek a költségek azonban elsö megjelenési formájukat tekintve szintén forgóeszközök. Költséggé akkor válnak, amikor a gyártás során felhasználjuk azokat, eredeti megjelenési 
formájukat elvesztik, és értékük átmegy az új termék értékébe. Tehát a költségek - de csak a közvetlen költségek (az elöállitási költség) - vagyonná transzformálódnak. A közvetett költségek (a gazdasági általános költségek) - mivel készletekre nem terhelhetök - úgymond rejtve maradnak, nem jelennek meg a készletek értékében. A vagyonná transzformálódó költségek megjelenési formái tehát a készlet és követelésállomány.

Miután áttekintettük az összefüggéseket, definiálhatók a forgóeszközök azon elemei, amelyek a körforgás, és a folyamatos termelés biztosításában betöltött szerepük alapján szükséges, a kapcsolódó fogalmak egyértelmüen értelmezhetök.

\section{A forgóeszközök fogalom tágabb kategória, mint a forgótöke.}

- A forgótöke a forgóeszközök körforgásának folyamatában, egy adott idöszakra vonatkozóan, a folyamatos termelés biztosítása érdekében, a termelési folyamat(ok) és a termelés szervezésének sajátosságai által meghatározottan, állandóan megjelenö vagy jelen lévö forgóeszköz-féleségek tökeként funkcionáló állományértéke. Elemei; a folyamatos termelés viteléhez nélkülözhetetlen készletek, követelések és a pénzeszközök biztonsági pénzkészlet hányada.

- Az idényszerüen jelentkezö forgóeszközök azok, amelyek a forgótökén felül jelentkeznek. A gazdálkodás gyakorlatát alapul véve a körforgás készenléti és ráfordítási szakaszában, készletekben és a készletekre nem felosztható, közvetett költségek, mint készpénzköltségek formájában jelennek meg és rejtve maradnak. A körforgás megtérülési szakaszában követelésekben, forgatási céllal vásárolt értékpapírokban és pénzeszközökben lehetnek jelen.

- A forgóbefektetés az idényszerüen jelentkezö forgóeszközök azon állományértéke, amely a folyamatos termelés inditásától a megtérülésig (árbevétel realizálásáig) felmerül.

Kiemelten kell megemlíteni, hogy a forgótőke kifejezésben a „forgó” jelző csak arra utal, hogy a forgóeszközök e hányada tökeként funkcionál, tehát állandó jelleggel le van kötve. Ez a tőke tehát nem ,forog". A bennük lekötött tőke felszabadítása csak úgy lehetséges, ha pl. a biztonsági készletszintet csökkentjük, rövidebb fizetési határidöt adunk, stb. ez utóbbi esetben viszont akár azzal is számolnunk kell, hogy vevöket veszitünk, mert a rövidebb fizetési határidöt a vevök adott hányada nem tudja vállaini.

A példaként hozott anyacsavargyártást alapul véve a forgótőke elemei tehát az alábbiak lesznek:

Készletek:

- Alapanyag (a gömbvas biztonsági készlet szintje, 5 nap termelésének megfelelö mennyiség)

- Félkész termék (szeletelt gömbvas, 5 nap termelésének megfelelö mennyiség)

Követelések:

- Késztermék (anyacsavar, 5 nap termelésének megfelelö mennyiség)

Az értékesítés üteme és a fizetési határidőnek megfelelően az átlagos havi záró Követelésállomány. (Állományértéke az elfogadott feltételek miatt egy hónap nettó árbevételének 67\%-a)

Pénz: (A biztonsági pénzkészlet, például egy havi bér és a közterhek)

A forgóeszközök föbb csoportjairól, a termelési folyamatban betöltött szerepükröl az 1 . táblázatban közöltek adnak tájékoztatást. 
1. táblázat. A forgótőke és az idényszerüen jelentkező forgóeszközök elemei

\begin{tabular}{|c|c|c|}
\hline MEGNEVEZÉS & FORGÓTŐKE & $\begin{array}{l}\text { IDÉNYSZERÜEN } \\
\text { JELENTKEZÖ } \\
\text { FORGÓESZKÖZÖK }\end{array}$ \\
\hline \multicolumn{3}{|l|}{ 1. KÉSZLETEK } \\
\hline - Anyagok & Biztonsági vagy tơrzskészlet & $\begin{array}{lll}\text { Biztonsági készleten felüli } \\
\text { készletállomány }\end{array}$ \\
\hline - Befejezetlen termelés & $\begin{array}{l}\text { A termelésszervezés által } \\
\text { meghatározott állományérték }\end{array}$ & $\begin{array}{l}\text { A forgótőke állományértékét } \\
\text { meghaladó készletállomány (A } \\
\text { mezögazdaság esetében ez nem } \\
\text { jelentkezik) }\end{array}$ \\
\hline - Félkész termékek & $\begin{array}{l}\text { A termelésszervezés által } \\
\text { meghatározott állományérték }\end{array}$ & $\begin{array}{l}\text { A forgótőke állományértékét } \\
\text { meghaladó készletállomány }\end{array}$ \\
\hline $\begin{array}{l}\text { - Növendék, hizó és } \\
\text { egyéb állatok }\end{array}$ & $\begin{array}{l}\text { A tenyészállat utánpótlást } \\
\text { szolgáló állomány }\end{array}$ & $\begin{array}{l}\text { A tenyészállat utánpótlást } \\
\text { meghaladó állatállomány értéke }\end{array}$ \\
\hline - Aruk & $\begin{array}{l}\text { A termelésszervezés által } \\
\text { meghatározott állományérték }\end{array}$ & $\begin{array}{l}\text { A forgótöke állományértékét } \\
\text { meghaladó készletállomány }\end{array}$ \\
\hline $\begin{array}{l}\text { - Készletre adott } \\
\text { elólegek }\end{array}$ & & 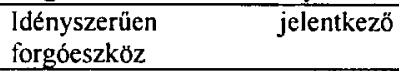 \\
\hline - Késztermékek & $\begin{array}{l}\text { A termelésszervezés által } \\
\text { meghatározott állományérték }\end{array}$ & $\begin{array}{l}\text { A forgótőke állományértékét } \\
\text { meghaladó készletállomány }\end{array}$ \\
\hline \multicolumn{3}{|l|}{ 2. KÖVETELÉSEK } \\
\hline $\begin{array}{l}\text { - Követelések } \\
\text { áruszálltísbobl } \\
\text { és szolgáltatásbol. }\end{array}$ & $\begin{array}{l}\text { A vállalat kereskedelmi } \\
\text { politikája függvényében } \\
\text { tervezett állományértékét }\end{array}$ & $\begin{array}{l}\text { A forgótöke állományértékét } \\
\text { meghaladó követelésállomány }\end{array}$ \\
\hline $\begin{array}{l}\text { - Követelesek kapcsolt } \\
\text { vállalakozásban szemben }\end{array}$ & $\begin{array}{l}\text { A termelésszervezés által } \\
\text { meghatározott állományérték }\end{array}$ & $\begin{array}{l}\text { A forgótöke állományértékét } \\
\text { meghaladó kơvetelésállomány }\end{array}$ \\
\hline $\begin{array}{l}\text { - Követelések egyeb } \\
\text { részesedési viszonyban } \\
\text { lévö vállalkozással } \\
\text { szemben. }\end{array}$ & \multicolumn{2}{|c|}{ A konkrét viszonyok ismeretében dönthető el } \\
\hline - Váltókövetelések & \multirow{3}{*}{ Nem elemei a korforgásnak } & \multirow{3}{*}{$\begin{array}{c}\text { Teljes állományértékük } \\
\text { idényszerüen jelentkező } \\
\text { forgóeszkoz }\end{array}$} \\
\hline - Adott elölegek & & \\
\hline $\begin{array}{l}\text { - Egyéb követelések } \\
\text { ERTÉKPAṔROK }\end{array}$ & & \\
\hline 4. PÉNZESZKÖZÖK & A biztonsági pénzkészlet & $\begin{array}{l}\text { A biztonsági pénzkészleten felüli } \\
\text { állományérték }\end{array}$ \\
\hline
\end{tabular}

Forrás: Szerzök saját munkája

\section{A KÉSZLETEK SZEREPE A GAZDÁLKODÁSBAN}

A termelési típusú vállalatok esetében a forgóeszközök van túlsúlyban. Ebböl következik, hogy a forgóeszközökkel való gazdálkodás hatékonyságát a készletekkel való gazdálkodás alapvetöen meghatározza. Az elméleti összefüggések tárgyalásánál láttuk, hogy a folyamatos termelés vitelének egyik elengedhetetlen feltétele, - a termelési folyamatot, mint termék elöállítási rendszert és az adott termék ellátási láncot alapul véve - a készletek megjelenése a forgóeszközök körforgásában. Természetesen ez nem jelenti azt, hogy a vertikum valamennyi szereplöjénél szükségszerü a készletek jelenléte. Jól példázza ezt a „Just in Time” termelési filozófia gyakorlati alkalmazása is, mely esetben az ellátási lánc szereplöinél csak a végtermék elöállítójánál nem képzödnek ,alapanyag” készletek. Olyan termelési folyamatok is vannak, például a szolgáltatásokon belül a vendéglátás, ahol az alapanyagkészletek jelentik azt a puffert, amelyek nélkülözhetetlenek ahhoz, hogy a termelés sajátosságaiból eredő 
bizonytalansági tényezőket kiküszöböljük, mivel nem tudjuk megtervezni termék szinten, hogy a betérö vendég mit fog rendelni. Ezen túlmenően pl. az élelmiszerek eltarthatósága, a tárolási idöre vonatkozó elöirások felülírják és adott esetben $\mathrm{ki}$ is zárják a készletgazdálkodás optimalizáláshoz használható ismert összefüggések alkalmazását. Lehetne még példákat hozni az ágazati illetve termelési folyamatok sajátosságaival magyarázható raktározást érintő területekre, pl. a mezőgazdasági termelés szezonális jellege (szezonális termékek), ez utóbbiak más iparágaknál is elöfordulnak. A készletek szerepe, funkciója, állományértékének alakulása, struktúrája stb. tehát függ

- a termelési folyamat sajátosságaitól,

- a kapcsolódó menedzsmentdöntésektől,

- és a készleteknek a termelési folyamatban betöltött szerepétől is.

A készleteket a termelési folyamatban betöltött szerepük alapján az alábbi készletcsoportokra bonthatjuk:

- A biztonsági, vagy törzskészlet, azt a minimális készletszintet jelenti, amely alá a folyamatos termelés biztosítása érdekében nem csökkenhet a készlet annak érdekében, hogy készlethiány ne forduljon elő. Végső soron az alapanyag ellátás kockázatainak a kiküszöbölését biztosítja. Mivel állandó jelleggel le van kötve, tökeként funkcionál, azaz a forgótőke eleme.

- A biztonsági készleten felül jelentkezö készlet a folyamatos termelés igényéből eredeztethető, annak kielégítését szolgálják.

- A „szabad” készletállomány azt a készletmennyiséget jelenti, amely a rendelések ütemezésével és a rendelt mennyiséggel összefüggésben, a folyamatos termelés alapanyagigénye, és a biztonsági készletszint felett, az adott időegység (pl. az adott hónap végén) zárókészleteként jelenik meg.

A készletgazdálkodással összefüggésben további készletszinteket is szükséges értelmezni, melyek az alábbiak:

- A maximális készletszint a biztonsági készletszint és az egyszerre rendelt mennyiség összege.

- A jelzökészlet az a készletszint, amely a rendelés feladásától a készlet beérkezésig felhasználásra kerül. (Az utánpótlási időtartam alatt felhasznált készlet mennyisége.)

\subsection{A KÉSZLETGAZDÁLKODÁS KÖLTSÉGEI}

A készletgazdálkodásban az előzőekben értelmezett készlet-féleségeknek fontos szerepük van, állományértékük alakulása nagymértékben befolyásolja a készletgazdálkodás gazdasági terheinek, azaz költségeinek alakulását. A készletgazdálkodás optimalizálásához ismert és alkalmazott, illetve gyakorlati alkalmazásra javasolt módszerek, algoritmusok használhatósága érdekében fontos értelmezni az összefüggésekben szereplő változók tartalmát is. A készletgazdálkodás költségeit és azok föbb jellemzőit a 2. táblázatban foglaltuk össze. 
2. táblázat. A készletgazdálkodás összes költségének fontosabb tételei

\begin{tabular}{|c|c|c|c|}
\hline \multirow{2}{*}{$\begin{array}{c}\text { Csoport } \\
\text { sorszáma }\end{array}$} & \multirow[b]{2}{*}{ A költség megnevezése } & \multicolumn{2}{|r|}{ A költség jellemzöje } \\
\hline & & Állandó & Változó \\
\hline I. & $\begin{array}{l}\text { 1.Raktáros munkabére és kỏzterhe } \\
\text { 2.Üzemeltetés költsége (fütés/hütés, világitás, stb.) } \\
\text { 3. Épitményadó } \\
\text { 4. Értékcsokkenési leírás } \\
\end{array}$ & 1. & $\begin{array}{c}2 ; 3 ; 4 \\
\text { Az egységnyi készlettel } \\
\text { arányosan változó költségek }\end{array}$ \\
\hline II. & $\begin{array}{l}\text { 1. Rendelési költség (kommunikáció: telefon, e-mail, } \\
\text { stb.) } \\
\text { 2.Beszállitás koltsége } \\
\text { 3.Adminisztrativ költségek (nyilvántartás) }\end{array}$ & - & $\begin{array}{c}1 ; 2 ; 3 \\
\text { A rendelés számával } \\
\text { arányosan válto:ó költségek }\end{array}$ \\
\hline III. & $\begin{array}{l}\text { 1.Betárolás költsége } \\
\text { 2. Vám, illetékek } \\
\text { 3. Adminisztratív költségek }\end{array}$ & - & $\begin{array}{c}1 ; 2 ; 3 \\
\text { A rendelt mennyiséggel } \\
\text { arányosan váltosó költségek }\end{array}$ \\
\hline IV. & $\begin{array}{l}\text { 1. Haszonáldozati költség } \\
\text { 2.Üzemviteli hitel kamata } \\
\text { 3.Hiánykơltség }\end{array}$ & 1. & $\begin{array}{c}2 ; 3 \\
\text { Az egységnyi készlettel } \\
\text { arányosan változó költségek }\end{array}$ \\
\hline
\end{tabular}

Forrás: Szerzők saját munkája

A 2. táblázatban vázolt költségstruktúra a problémakör elméleti megközelítését jelenti. A gyakorlati alkalmazás során az egyes, elméletileg értelmezhető költségtételek egzakt lehatárolása vagy számszerüsítése nem valósítható meg, vagy adott esetben a költség kis részaránya, súlya miatt, stb. akár figyelmen kivül is hagyható/k. Ilyen költségnek lehet tekinteni pl. a hiányköltséget, amely a készlethiányból adódó árbevétel kiesést jelenti. Nehezen számszerüsíthetőnek kell tekinteni a raktár üzemeltetésének változó költséghányadát is, ami a raktárkapacitással, azaz a raktár méretével van összefüggésben. A raktárkapacitást viszont a maximális készletszint és a fajlagos kapacitás alapján tervezzük, a maximális készletszintet pedig a biztonsági készlet, és az egyszerre rendelt mennyiség összege adja. Ez utóbbi viszont az időszak szükséges alapigénye és a kapcsolódó költségek ok-okozati összefüggéséböl számszerüsíthetö az ismert készletgazdálkodási modellek és alkalmazható matematikai összefüggések felhasználásával. A 2. táblázatban szereplö költségtételek föbb sajátosságai az alábbiakban foglalható össze:

Az $1 . / 1$. költségtétel adott termelési kibocsájtás és termelésszervezés mellett állandónak tekinthető. A költség állandó jellege miatt, a készletgazdálkodás optimalizálásához figyelmen kívül lehet hagyni.

Az I./2 költségtétel, a készletszintek által meghatározott raktárkapacitás-igényen keresztül, arányosan változó költségnek tekinthető. Az optimális rendelési tételnagyság (EOQ) összefưggésében szereplő készlettartási ráta ,r” értékében szerepelnie kell.

Az építményadó (I./3 költségtétel) arányosan változó költség, a raktár méretével arányosan változik, ami viszont a készletszinttel van összefüggésben, tehát a készlettartási rátában szintén szerepelnie kell.

Az értékcsökkenési leirás (I./4) a raktárkapacitás alakulásával arányosan változik $\left(\mathrm{Ft} / \mathrm{m}^{2}\right)$, a fajlagos beruházási költség és a leirási kulcs által meghatározottan. Szerepeltetése a készlettartási rátában szintén indokolt.

A 2. táblázatban szereplö $1 /$. és III. költségcsoportok értelmezése és számszerūsítése nem jelent problémát. A rendelések számával illetve a rendelt mennyiséggel arányosan változó költségként értelmezhetök. Az EOQ modellbe minden nehézség nélkül számszerüsíthetök és beépithetök.

A $I V$. csoportba tartozó költségtételek közül, a hiányköltség (3) a termelés jelenlegi színvonala mellett nem életszerü, és számszerüsítése objektív módon nem is lehetséges, mivel 
tervezésnél az erőforrások kapacitását mindig 100\%-ra tervezzük. Ebből eredően figyelmen kivül hagyható.

A $I V . / l$. tétel értelmezése és számszerüsítése a forrásmunkákban véleményünk szerint szakmailag nem megfelelö, mivel a készlettartási rátába az alternativ befektetés rátáját építik be. Az üzemviteli hitelkamat kezelése $I V . / 2$ tétel megegyezik a haszonáldozati költségével. A cikk kertében - a későbbiekben - bizonyítjuk ezen algoritmus korrekciójának szükségességét. A fentiekböl egyértelmüen következik, hogy a készletgazdálkodás optimalizálásának központi kérdése az optimális rendelési készletmennyiség meghatározása, az alkalmazható összefüggésben szereplö egyes változók - különös tekintettel a készlettartási rátára számszerüsítése. A megválaszolandó kérdés tehát: Mennyit és mikor rendeljünk?

\subsection{A KÉSZLETTARTÁSI RÁTA DIAGNÓZISA}

A hazai és nemzetközi szakirodalom több módszert is ismer az optimális rendelési tételnagyság meghatározására (Koltai, 2006; Vörös, 2010; Kovács, 2001; Chrissoleon et. al., 2006), melyből a három legjelentősebb:

- Legkisebb egységköltség (LUC) modell

- Legkisebb összes költség (LTC) modell

- Gazdaságos rendelési tételnagyság (EOQ) modell

A fenti modellek közül a LUC és az LTC iterációval közelit a legkisebb költséget jelentö megoldáshoz, addig az EOQ modell egy meghatározott formula segítségével adja meg a rendelendő mennyiséget. A modell összefüggése:

$$
\mathrm{EOQ}=\sqrt{\frac{2 A * D}{v * r}}
$$

EOQ: Optimális rendelési tételnagyság (természetes mértékegység $\mathrm{db}, \mathrm{t}, \mathrm{stb}$.)

A: Egy rendelés költsége (Ft/rendelés)

D: Időszak alapanyag igénye (természetes mértékegység, $t, m$, stb.)

v: Egységnyi alapanyag beszerzési ára ( $\mathrm{Ft} / \mathrm{t}, \mathrm{Ft} / \mathrm{m}$, stb.)

r: A készlettartási költség egységnyi készletértékre jutó értékét számszerüsíti (Ft/Ft/idöszak). Kifejezhetö százalékos formában is.

$A z$ összefüggés számlálójában szerepelő változók $(A ; D)$ számszerüsítése nem jelent problémát. A nevezőben szereplő „v" szintén ismert, a készlettartási ráta „r" számszerüsítése viszont több értelmezésbeli és számszerüsítési problémát is felvet, azért mert az összefüggésben ennek értéke döntő mértékben befolyásolja az $\mathrm{EOQ}$ alakulását. A szakirodalom nem, vagy felszínesen foglalkozik az „r" értékének meghatározásával. Márpedig, a készlettartási ráta a központi tényezője az összefüggésnek, mivel egyidejüleg ez határozza meg - nagyságának függvényében - jelentös mértékben az egyszerre rendelt mennyiséget és ez által a kritikus készletszinteket és ezeken keresztül a raktározás összes költségét is.

Az ismert összefüggéseket felhasználva gazdasági tényadatokon alapuló modellszámítással elemeztük az alapanyagok készletgazdálkodási költségeinek alakulását a készlettartási ráta függvényében. A modellben egy öltönyöket gyártó vállalat alapadatait vettük alapul. A modellszámítással összefüggésben természetesen nem az abszolút nagyságrendek, hanem az összefüggések és a jelentkező tendenciák a fontosak, amelyek a folyamatos készlettartást igénylö termelési folyamatokra általánosíthatók. A kapott eredmények alapján kiemelten kell megemlíteni, hogy az $E O Q$ rendkivül érzékeny a készlettartási ráta nagyságára, amit a 2. ábra szemléltet. 


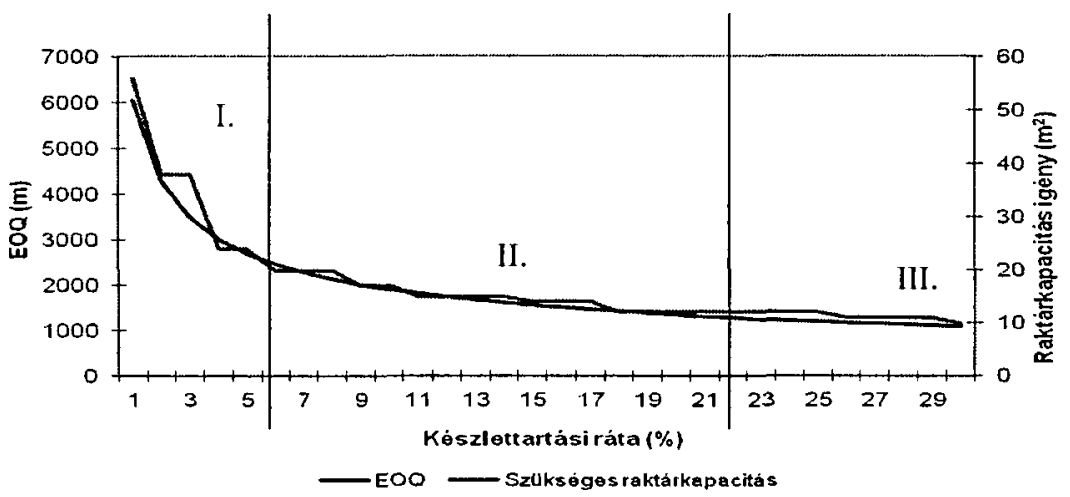

2. ábra. A készlettartási ráta, az EOQ és a szükséges raktárkapacitás alakulása

Forrás: Szerzők saját munkája

A 2. ábra alapján - a gyakorlati alkalmazást is figyelembe véve - kiemelendö, hogy három tartományt lehet elkülöníteni a készlettartási ráta EOQ-ra gyakorolt hatását alapul véve. A görbe lefutása alapján egyértelmü, hogy a racionális tartományt a II. jelenti. Azaz a készlettartási ráta adott számszerü értéke felett - a modellben ez $20 \%$ - nincs jelentősége a raktárkapacitásra gyakorolt hatást illetỏen. Az I. tartomány szintén irreálisnak értékelhetö. Az elözőek tehát egyértelmüen bizonyítják, a készlettartási ráta számszerüsítésének fontosságát. (A javasolt algoritmust a későbbekben részletesen ismertetjük.)

A raktárkapacitás igény ismeretén túlmenően vizsgálni szükséges a készletezési költségek alakulását is. A modellszámítás eredményeit a költségek alakulása szempontjából a 3. ábra szemlélteti. A 3. ábra jól kifejezei, hogy az ,r” növelésével a készletezés összes költsége csökken, majd egy adott érték után növekedni kezd. Kell, hogy létezzen tehát egy olyan készlettartási ráta, amely mellett az adott rendelési és beszerzési költségek esetén, a készletgazdálkodási költség minimális. Az eredmények alapján megállapítható, hogy a költség minimuma a II. tartományban helyezkedik el. Ebböl eredően a készlettartási ráta is e tarományban keresendö a gyakorlati alkalmazás során.

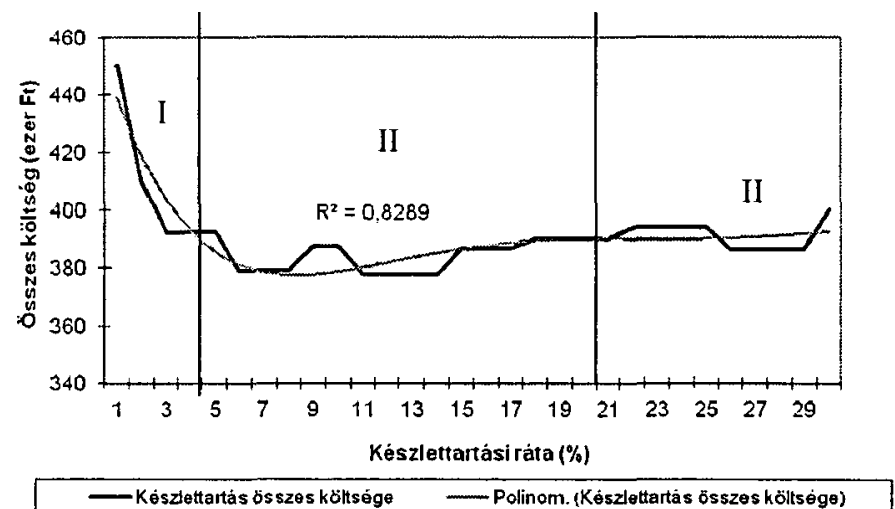

3. ábra. A készlettartás összes költsége és a készlettartási ráta kapcsolata

Forrás: Szerzők saját munkája 


\subsection{A KÉSZLETTARTÁSI RÁTA SZẢMSZERÜSÍTÉSÉNEK JAVASOLT ALGORITMUSA}

A kutatási eredményeink alapján a készlettartási ráta számszerüsítésének főbb tételei az alábbiak:

- készletezési költség,

- haszonáldozati költség,

- hiány költség,

- üzemviteli hitel kamata

A 2., 3. ábra mutatja, hogy a ráta helyes számszerüsítésének nagyon komoly hatásai vannak, amelyekkel feltétlenül indokolt számolni. Ha azt is figyelembe vesszük, hogy egy nagyvállalat esetében milyen nagyságrendeket jelent(het) a készletek alakulása, ennek hatása még hatványozottabban jelentkezik. A problémásnak itélt kérdések javasolt algoritmusa az alábbiakban foglalhatók össze:

1/ Az anyagszükséglet és a biztonsági alapanyagkészlet számszerüsítése nem okoz problémát. Ezek ismeretében számszerüsíthető az átlagos alapanyagigény. Az ár ismeretében az átlagos alapanyagkészlet értéke, az alábbi összefüggések alapján:

\section{Átlagos készletérték $=$ Átlagos készlet $\times$ egységár \\ Biztonsági készletérték $=$ Biztonsági készlet $\times$ egységár}

2/ A raktározás/készlettartás költségei tervezhetők. (Állandó és változó költségek szerinti bontásban.)

3/ Meghatározzuk az egységnyi átlagos készletértékre jutó raktározási költséget, az alábbi algoritmus alapján.

Egységnyi átlagos készletértékre jutó raktá rozási költség $=\frac{\text { Raktározási változó költség }}{\text { Átlagos készletérték }}$

Ez az érték úgy is értelmezhető, hogy a raktározási költség hány \%-a a készletértéknek, ebböl eredően az egységnyi készlet beszerzési árának. Eljutottunk tehát a készlettartási ráta egyik elemének, a készletezési költségnek a készlettartási rátába való beépítéséhez, számszerüsítéséhez.

4/ A haszonáldozati költség rátảjának kezelése az alábbi algoritmussal megoldható. A haszonáldozati költség - ahogy ez ismert - csak a tőkeként funkcionáló eszközlekötésre értelmezhetö, azaz a forgótőke állományértékére (biztonsági vagy törzskészlet).

$$
\begin{gathered}
\text { A haszonáldozati költség }(\mathbf{F t})=\text { Biztonsági készletérték } \times \mathbf{r} \\
\text { ahol } \\
\text { r: Alternativ tökebefektetés hozamrátája }
\end{gathered}
$$

A továbbiakban a haszonáldozati költséget viszonyitjuk az átlagos készletértékhez, és százalékos formában értelmezzük. Az elmondottak alapján adódik;

Haszonáldozati költség készlettartási rátája $(\%)=\frac{\text { Biztonsági készletérték } * r}{\text { Átlagos készletérték }} * 100$

5/ Az üzemviteli hitel kamatlába készlettartási rátára gyakorolt hatásának számszerüsítése nem jelentheti a kamatláb mechnaikus „beemelését” a rátába. Figyelembevételének fontossága nem vitatható, de szakmailag elfogadható és védhető algoritmust célszerü 
alkalmazni. Ismert, hogy a folyamatos müködés üzemviteli hitelállományának, és kamatának számszerüsítése a pénzforgalmi tervben történik. A pénzforgalmi terv tartalmazza a müködés pénzáramait, a müködési pénzáramok pedig a bevételek és kiadások egyenlegei. Tehát ismert az összes bevétel és összes kiadás. A kiadások összegében ismert a felhasznált alapanyag kiadási pénzárama is. $\mathrm{Az}$ adatok ismeretében a javasolt algoritmus az alábbiakban összegezhetö:

a/ Meghatározzuk a kiadások százalékos megoszlását.

b/ A megoszlás arányában megosztjuk az üzemviteli hitelek kamatának összegét.

c/ Számszerüsitjük az üzemviteli kamatláb készlettartási rátáját az alábbi összefüggés alapján

Üzemviteli hitel kamatlábának készlettartási rátája (\%):

$$
\frac{\text { Üzemviteli kamat arányosított összege }}{\text { Átlagos készletérték }} * 100
$$

6/ A számszerüsített értékeket összegezzük, és így megkapjuk a készletartási rátát.

7/ Ha szükséges, célszerü korrekciót, érzékenységi vizsgálatot végezni, korrigálni a rendelkezésre álló tényadatokkal. Továbbá adott feltételek keretei között, arra is sor kerülhet például ahol szezonalitás van - hogy egy-egy idöszakot külön-külön kezeljünk, tekintsünk tervezési egységnek.

A ráta helyes számszerüsítésének tehát nagyon komoly gazdasági hatásai vannak, amelyekkel feltétlenül indokolt számolni. Ha azt is figyelembe vesszük, hogy egy nagyvállalat esetében milyen nagyságrendeket jelenthet a készletek alakulása, ennek szerepe még hangsúlyosabban és hatványozottabban jelentkezik.

\section{3. ÖSSZEFOGLALÁS, KÖVETKEZTETÉSEK}

A vállalatok hosszú távú pénzügyi helyzetének stabilitásában az időbeliség elvének érvényesítése nem nélkülözhetö. Ennek elengedhetetlen feltétele, hogy a folyamatos termelés viteléhez szükséges termelési eszközök tőkeként funkcionáló állományértékének finanszírozása csak lejárat nélküli saját, illetve hosszú lejáratú idegen forrásokkal történhet. A tanulmány keretében - több éves kutatómunka eredményeként - definiáltuk a forgótőke, idényszerüen jelentkezö forgóeszközök és a forgóbefektetés fogalmakat. E fogalmak új értelmezése lehetővé teszi a szakirodalomban jelen időpontig nem tisztázott, illetve tévesen értelmezett fogalmak, és ok-okozati összefüggések feltárását. A feltárt összefüggések tisztázása felhívja a figyelmet a terület elemzéséhez alkalmazott pénzügyi mutatószámok szükséges korrekciójára is. A gazdasági hatások számszerüsítése kapcsán bizonyitottnak tekintjük, hogy a forgóeszközökkel való gazdálkodásban meghatározó szereppel bíró készletgazdálkodás optimalizálásához a szakirodalomban megtalálható és javasoit módszerek gyakorlati felhasználásánál a tanulmányban közölt algoritmusok alkalmazása nem nélkülözhetö.

\section{IRODALOMJEGYZÉK}

Bárány, L-né. (főszerk.) (2003): Magyar Nagylexikon. Budapest: Akadémiai Kiadó. p. 628. Brealey-Myers (1993): Modern vállalati pénzügyek. Első kötet. Budapest: Panem Kft. Második javított kiadás. pp. 463-484.

Brüll, M. (fószerk.) (1987): Közgazdasági Kislexikon: Budapest.p.173.

Chrissoleon P. et. al. (2006): Stohastic Modeling of Manufacturing Systems, pp. 286-290. Springer, Berlin 
Hámori, É. (2000): Zseb-közgazdaság érdekelteknek és érdeklödőknek. Budapest: Szerzői kiadás. p. 173.

Illés, I-né (1994): Társaságok pénzügyei. Budapest, SALDO Pénzügyi Tanácsadó és Informatikai Rt. pp. 270-361.

Koltai T. (2006): Termelésmenedzsment. Budapest: Typotex Kiadó.

Kovács Z. (2001): Termelésmenedzsment. Veszprém: Pannon Egyetemi Kiadó.

Muraközy, T.-Zánkai, G.(ed) (1973): Közgazdasági ÁBC. Budapest: Mezőgazdasági Kiadó, Közgazdasági és Jogi Kiadó. p.158.

Pupos T. (2011): Forgótőke-gazdálkodás. Budapest: Szaktudás Kiadó Ház Zrt. (Megjelenés alatt)

Pupos et. al. (2010): Forgótöke és elemeinek értelmezése valamint a forgótőkemenedzsment, Gazdálkodás, 54. évf. 5. szám, p. 488-498.

Pupos, T.- Demeter, Gy.(2004): Forgóeszközök, forgótöke és a mezögazdasági termelés BRÜLL, M. (föszerk.) (1987): Közgazdasági Kislexikon: Budapest.p.173.

Pupos, T. (2005): A tőkeszükséglet meghatározásának módszertani kérdései. In: Jávor A. (szerk.) A mezögazdaság tőkeszükséglete és hatékonysága. Debreceni Egyetem Agrártudományi Centrum, Agrárgazdasági és Vidékfejlesztési Kar. pp. 35-41.

T. Pupos -Zsolt P.- G. Horváth (2008): Methodological issues of determining capital needs. Banks and Bank Systems Volume 3, Issue 3, pp.31-34.

Vörös, J. (2010): Termelés- és szolgáltatásmenedzsment. Budapest: Akadémiai Kiadó. 